Diabetologia 4, 1-9 (1968)

\title{
ORIGINALS
}

\section{Human Growth Hormone as a Regulator of Blood Glucose Concentration and as a Diabetogenic Substance*}

\author{
R. Luft and E. Cerasi \\ Department of Endocrinology and Metabolism, Karolinska Hospital, Stockholm 60, Sweden
}

Received August 14, 1967

\begin{abstract}
Summary. Human growth hormone (HGH) has recently been shown to play a prominent role in the control of blood glucose homeostasis. Furthermore, it has long been known that administration of growth hormone in animals can induce a diabetes.like state. In human subjects, exogenous administration of $\mathrm{HGH}$ or hypersecretion of the endogenous hormone in acromegaly is accompanied by glucose intolerance in only about 25 per cent of the cases. - In this paper, data are presented which give a more diversified picture of the so-called diabetogenic action of HGH. It is suggested that HGH, although decreasing the peripheral utilization of glucose, is not a primary diabetogenic factor, since its insulinogenic action causes a compensatory hyperinsulinism, with normal glucose tolerance as the result. HGH is diabetogenic only in prediabetic subjects whose pancreas is unable to respond to the insulinogenic effect of the hormone. In such subjects, the diabetogenic action of HGH not being counterbalanced by a compensatory hyperinsulinism, glucose intolerance may result. Thus, $\mathrm{HGH}$ may be regarded as an additional factor for the development of diabetes, the major prerequisite being a preëxisting prediabetic state.
\end{abstract}

L'hormone de croissance humaine en tant que régulateur de la concentration du glucose sanguin et en tant que substance diabétogène

Résumé. Il a été démontré récemment que l'hormone de croissance humaine (HGH) joue un rôle prééminent dans la régulation normale de la glycémie. De plus, il est bien connu que l'hormone de croissance peut créer un état semblable au diabète chez l'animal. Chez l'homme, l'injection de HGH ou l'hypersécrétion de l'hormone endogène dans l'acromégalie est suivie d'intolérance au glucose seulement dans $25 \%$ des cas. - Dans ce travail nous présentons des données qui mettent l'action dite diabétogène de HGH dans un contexte plus nuancé. Nous suggérons que HGH, bien que diminuant l'utilisation du glucose par les tissus périphériques, n'est pas une substance primairement diabétogène, car l'effet insulinotrope de l'hormone cause une hyperinsulinémie compensatrice, qui à son tour normalise la tolérance au glucose. HGH est diabétogène exclusivement chez les sujets prédiabétiques dont le pancréas est incapable de répondre à l'effet insulinotrope de l'hormone. Chez ces sujets, la diabétogénicité de HGH n'étant pas surmontée par une hyperinsulinémie compensatrice, la tolérance au glucose sera anormale. Ainsi, HGH peut être considérée comme un facteur additif pour la pathogénèse du diabète sucré, la condition essentielle et primaire étant un état préexistant de prédiabète.

Menschliches Wachstumshormon als Regler der Blutzuckerkonzentration und als diabetogene Substanz

Zusammenfassung. Wie kürzlich gezeigt wurde, spielt das menschliche Wachstumshormon (HGH) eine wichtige Rolle bei der Kontrolle der Blutzucker-Homöostase. Ferner ist schon lange bekannt, daß die Verabreichung von Wachstumshormon an Tiere zu einem diabetesähnlichen Zustand führen kann. Beirn Menschen löst die Gabe der Substanz oder die Überproduktion des endogenen Hormons bei der Akromegalie nur in etwa $25 \%$ der Fälle eine Glucosetoleranzstörung aus. - In dieser Arbeit werden Resultate beschrieben, die ein detaillierteres Bild der sogenannten diabetogenen. Wirkung des HGH vermitteln. Wir möchten annehmen, daß das HGH, obwohl es den peripheren Glucoseverbrauch herabsetzt, kein primär diabetogener Faktor ist, da es über eine Insulinmehrausschüttung zu einem Hyperinsulinismus führt, der eine normale Glucosetoleranz bewirkt. HGH zeigt seine diabetogene Wirkung nur bei Prädiabetikern, deren Pankreas den stimulierenden Effekt des Hormons auf die Insulinausschüttung nicht beantworten kann. Bei diesen Personen kann eine Störung der Glucosetoleranz dadurch entstehen, daß die diabetogene Wirkung des HGH nicht durch einen kompensatorischen Hyperinsulinismus ausgeglichen wird. HGH kann daher als ein Zusatzfaktor bei der Diabetesentstehung angesehen werden, deren Hauptvorbedingung jedoch eine schon vorher bestehende prädiabetische Stoffwechselsituation darstellt.

Key-words: Human growth hormone, Growth hormone, Insulin, Diabetes mellitus, Experimental diabetes, Acromegaly, Pathogenesis of diabetes mellitus.
The role of the hypophysis in experimental diabetes was discovered by HousSAY and BIASOT'TI in 1930 by demonstrating that the severity of diabetes decreases following extirpation of the hypophysis, and increases again after implantation or injection of pars distalis of the pituitary gland. Young, in 1937, was able to produce diabetes in intact dogs by the administration of crude anterior pituitary extracts. In 1949, CoTES et al., and Houssay and ANDerson independently

* Presented as an invited lecture at the VI Acta Endocrinologica Congress, Helsinki, Finland, August 8th 12 th, 1967. demonstrated that growth hormone was the active substance in pituitary extracts which induced diabetes in the animals. With the demonstration in 1960 by IKKos and LUFT, that human growth hormone (HGH) could induce a transient diabetic state in human subjects similar to the experimental diabetes of the animal, the cycle of experimental evidence giving to growth hormone the role of a prominent diabetogenic substance was completed.

Three decades of intensive work has been devoted to the task of really proving that growth hormone $i s$ a diabetogenic hormone. Today we are in posession of 
new experimental data which gives a more diversified picture of HGH as a diabetes-inducing agent. A major asset to such studies with HGH has been the introduction of radioimmunological methods for the determination of HGH concentration in plasma (Hurrer and Grenewwood, 1962 ; RotH et al., 1963).

This presentation will deal mainly with the ability of HGH to raise the blood glucose concentration. Two aspects of this action will be discussed: 1 . the role of HGH in blood glucose homeostasis; and 2. HGH as a diabetogenic substance. The mechanism of action of the hormone will not be discussed.

\section{The significance of $H G H$ in blood glucose homeostasis}

The interest in this aspect of HGH action actually stems from the above studies showing that growth hormone in pharmacological doses could induce a diabetic state in animals. Later when HGH became available for studies in humans (Lr and PAPKofr 1956), and furthermore, the radioimmunological assay of HGH was introduced, we had for the first time the means to tackle the problem of the role of $\mathrm{HGH}$ in blood glucose homeostasis. This action of the hormone is most easily illustrated by depressing the blood sugar and recording, firstly how the administration of HGH influences the response of the blood glucose,

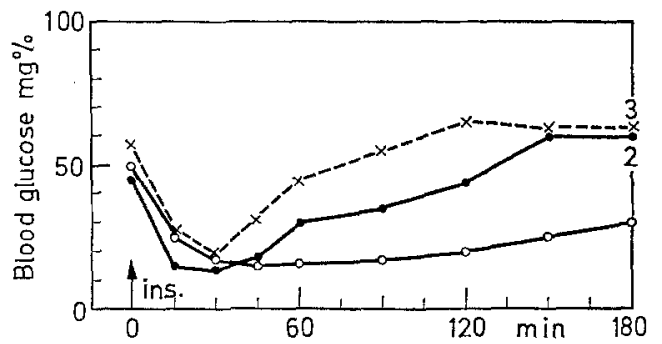

Fig. 1. Insulin tolerance test $(0.05$ units per $\mathrm{kg}$ body weight) in a patient with panhypopituitarism:

1. without replacement

2. on cortisone + thyroxine

3. on cortisone + thyroxine $+\mathbf{H G H}$

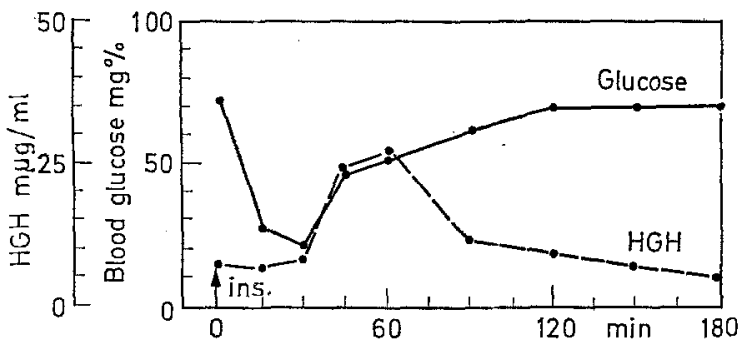

Fig. 2. Effect of insulin hypoglycaemia (0.05 units per $\mathrm{kg}$ body weight) on HGH concentration in plasma in a healthy subject

and secondly how the endogenous $\mathrm{HGH}$ production responds to the induced hypoglycaemia. Hypoglycaemia has mostly been induced by giving intravenously $0.05-0.1$ anit of insulin per $\mathrm{kg}$ body weight. By this means the blood sugar in healthy subjects is decreased to about $20 \mathrm{mg}$ per $100 \mathrm{ml}$, and returns to normal usually within 90 min.

In a patient with panhypopituitarism, unable to influence the reins of blood glucose homeostasis except for epinephrine, the situation is different. As seen in Fig. 1 blood glucose remained low during the whole insulin tolerance test. Administration of cortisone and thyroxine improved only slightly the hypoglycaemia unresponsiveness, whereas treatment with HGH brought the blood glucose curve to normal (LUFT, 1965).

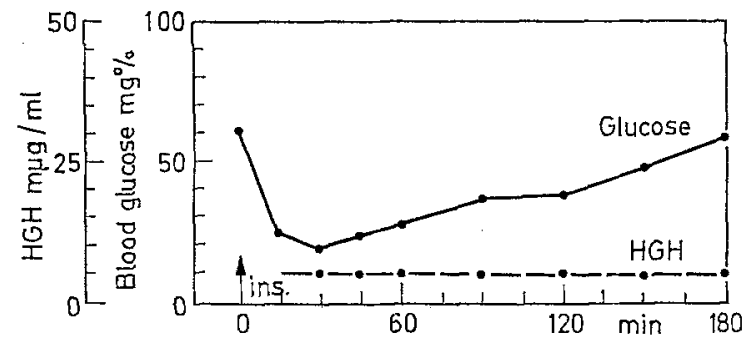

Fig. 3. Effect of insulin hypoglycaemia (0.05 units per $\mathrm{kg}$ body weight) on HGH concentration in plasma in a patient with pituitary dwarfism

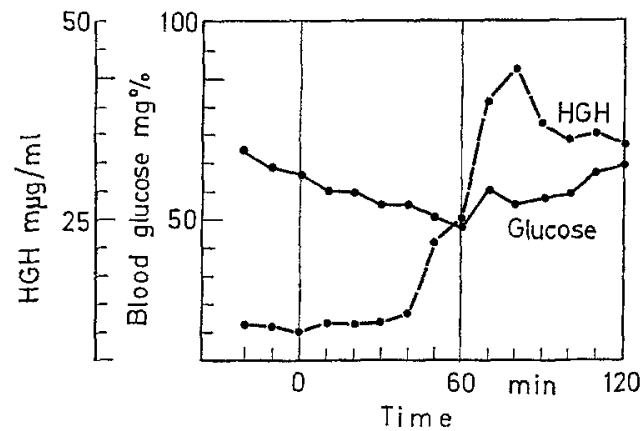

Fig. 4. Effect of a minor decrease in blood glucose level on HGH concentration in plasma. Insulin in a dose of 0.01 units per $\mathrm{kg}$ body weight infused during $60 \mathrm{~min}$

The second approach to the problem is by measuring plasma HGH during the insulin tolerance test. Fig. 2 shows, in a healthy subject, the increase in plasma HGH during such a test. When the pituitary is destroyed, as is so often the case in pituitary dwarfism, the plasma HGH level is not influenced by insulin hypoglycaemia (Fig. 3) (LuFT, 1965).

The insulin tolerance test does not simulate a physiological condition since it implies the depression of the blood sugar to exceptionally low values by the administration of comparatively large doses of insulin. The insulin loading better compares with tests used in endocrinology to demonstrate the functional capacity of a gland. Such a test does not necessarily give information on the physiological significance of the product of the gland. We may assume that blood glucose under normal conditions and even during prolonged starvation presumably does not fall more than $10-$ 
$15 \mathrm{mg}$ per $100 \mathrm{ml}$. In order to mimic physiological conditions we infused as little as 0.01 unit of insulin per $\mathrm{kg}$ body weight over a $60 \mathrm{~min}$ period (LUFT et al., 1966). Fig. 4 shows the result of such a test in a healthy subject. The blood glucose level decreased by only about $15 \mathrm{mg}$ per $100 \mathrm{ml}$ towards the end of the infusion period, and this minor decrease was accompanied by a remarkable $\mathrm{HGH}$ response.
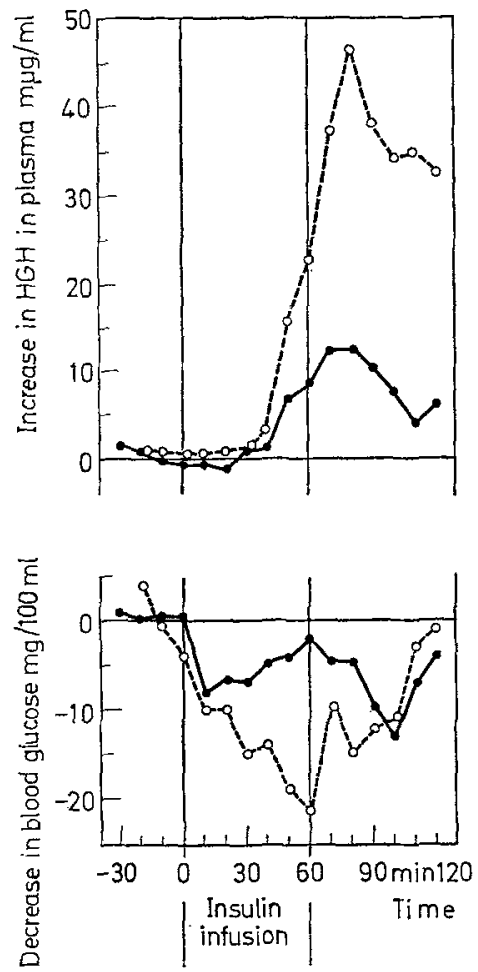

Fig. 5. Effect of different degrees of blood glucose depression on HGH concentration in plasma in a healthy subject

The sensitivity of the interrelationship between blood glucose and $\mathrm{HGH}$ is illustrated in Fig. 5. It shows that variations in this small depression of the blood sugar elicits HGH responses of different magnitude.

The diagram in Fig. 6 summarizes the results obtained in 21 such insulin infusion tests performed in healthy subjects. A decrease in blood glucose of at least $10 \mathrm{mg}$ per $100 \mathrm{ml}$ was almost always accompanjed by a substantial rise in plasma $H G H$. As a rule, the magnitude of rise in HGH followed the degree of hypoglycaemia obtained.

All these experiments demonstrate clearly the intimate relationship between the blood glucose level and the secretion of HGH. Therefore, it may certainly be concluded that $\mathrm{HGH}$ is of great significance for the maintenance of a normal blood glucose level.

In the above discussion of the effect of $\mathrm{HGH}$ on blood sugar homeostasis one of the major properties of the hormone has not been engaged, i.e. its promoting effect on bodily growth and protein synthesis, the prime characteristics of the normal somatotrophic activity of the anterior pituitary. It may then be asked what the biological fitness would be of a hormone which has the purpose of stimulating growth and, at the same time, varies markedly with minor changes in blood sugar. The discussion involves the two major biological properties of the hormone: its anabolic and adipokinetic or anticatabolic effects.

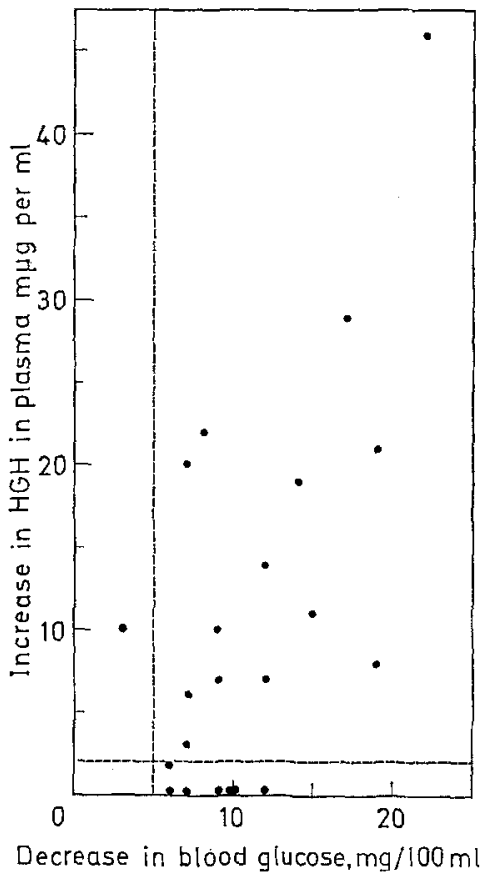

Fig. 6. Correlation between decrease in blood glucose and increase in plasma HGH. The broken lines denote the 2 S.D. for blood glucose and plasma HGH respectively

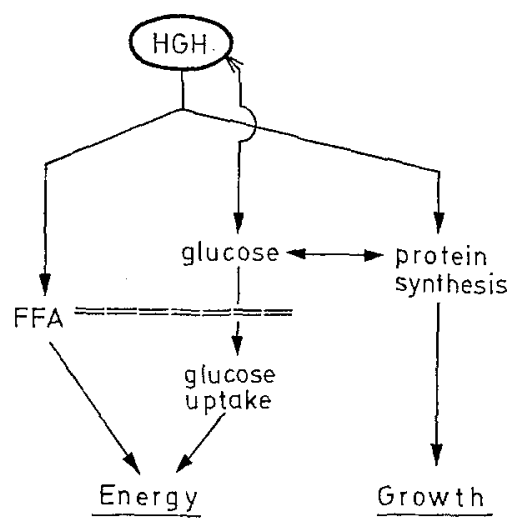

Fig. 7. The single-factor theory for the effect of HGH on energy metabolism and growth

The generally accepted view on these effects of $\mathrm{GH}$ is presented in Fig. 7. Its aim is to explain these activities as two actions of one and the same hormone (RABEN, 1965). The adipolinetic effect would serve the purpose of shifting cellular metabolism to the utilization of fat, whenever there develops a scarcity 
of carbohydrate. At the same time, through a decrease in glucose disappearance from the blood, the breakdown of protein for the purpose of gluconeogenesis is said to be diminished. Thus, through one mechanism FFA release - the same hormone would act as an anabolic and anticatabolic agent. The increase in $\mathrm{GH}$ in plasma during hypoglycaemia might then be an expression of a feed-back mechanism between blood glucose level and GH release. This explanation of GH action actually reduces it to a purely anticatabolic agent.

A second working hypothesis for GH action, introduced by LEVINE and LUFT (1964) puts forward the concept of two physiologically distinct hormones, which may or may not be secreted together under varying circumstances: the somatotrophin proper (STH) and the adipokinetic factor (AK) (Fig. 8). AK then corresponds to the anticatabolic property mentioned above, and its secretion is evoked by the signal of carbohydrate lack. STH promotes epiphyseal proliferation and probably is the moiety responsible for the insulinogenic action of GH, thereby enhancing its anabolic effect. The signal for the liberation of STH is not known.
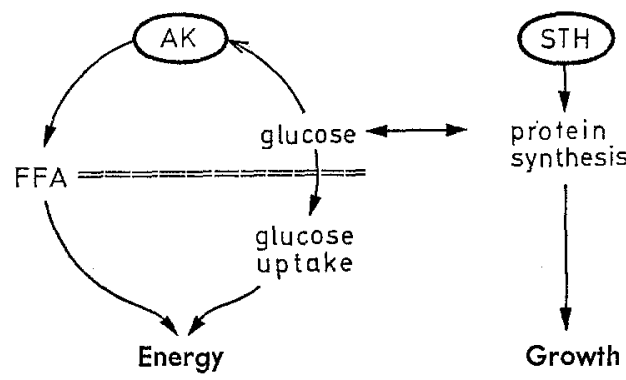

Fig. 8. The dual-factor theory for the effect of HGH on energy metabolism and growth

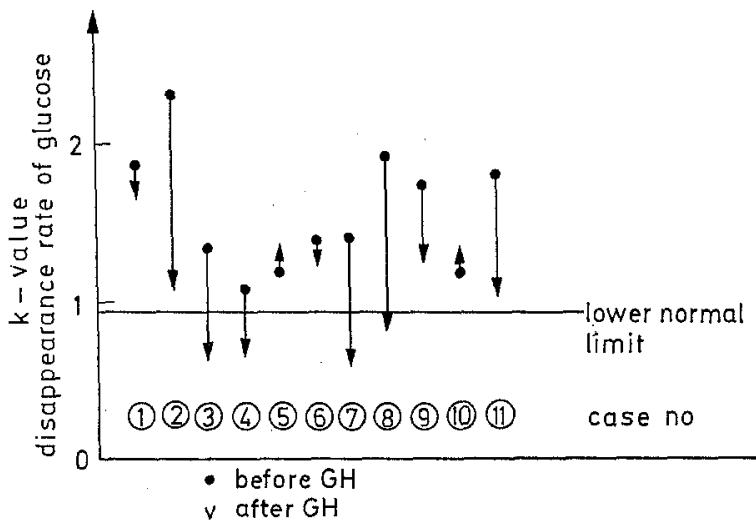

Fig. 9. Effect of HGH (30 mg daily for three days) on intravenous glucose tolerance in 11 healthy subjects

A third explanation of the dual action of GH has been presented by RuBINowTTz et al. (1966). According to these authors the anabolic actions of GH would become optimum in the presence of insulin, whereas the diabetogenic actions would be dominant in the absence of insulin.

Any of these theories as regards GH action may be the right one. We have to await the clarification of the chemistry of the GH molecule before it can be decided whether we are dealing with two hormones or two aspects of the actions of one and the same hormone.

\section{The diabetogenic action of $H G H$}

The fact that a hormone operates during hypoglycaemia by counteracting the effect of insulin does not carry the implication that this hormone must be diabetogenic. As a matter of fact we demonstrated in
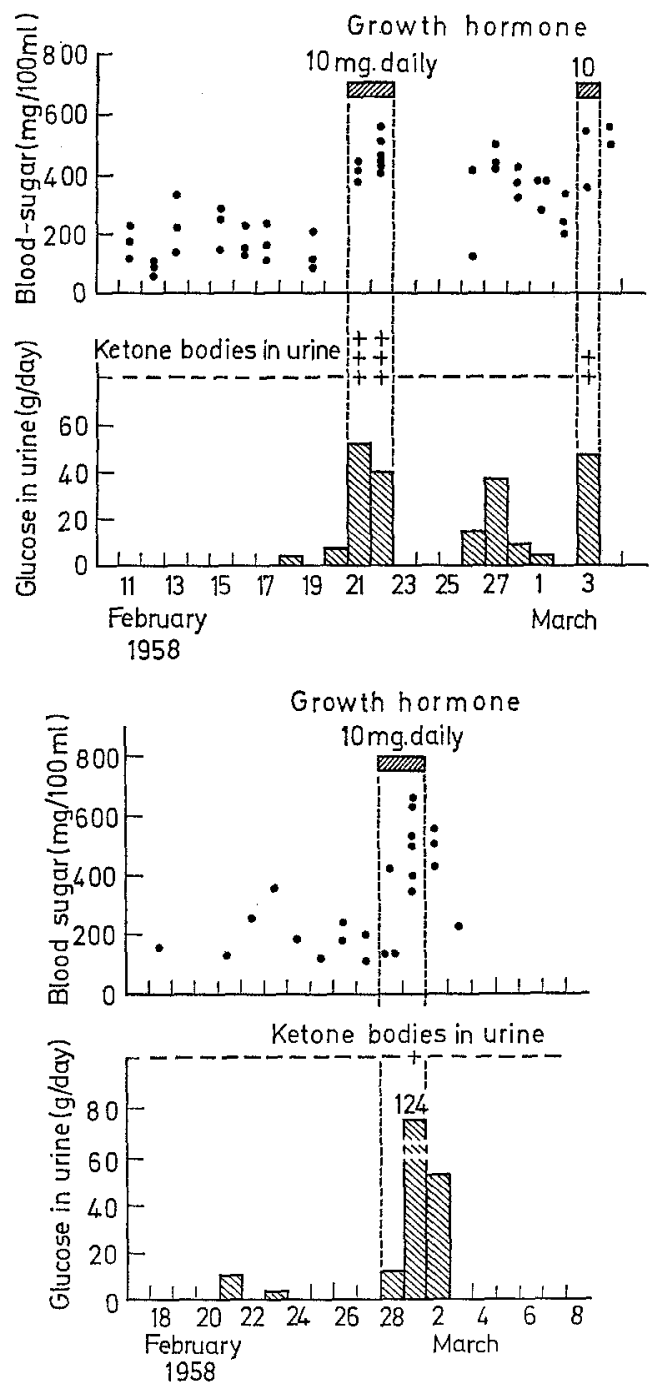

Fig. 10. Effect of HGH on the diabetic state in two hypophysectomized patients with juvenile diabetes

earlier experiments that HGH in a daily dose as high as $30 \mathrm{mg}$ had no significant effect on fasting blood sugar in 11 normal subjects, nor did it induce glucosuria (IKKos et al., 1962). 
On the other hand, there exist numerous experimental data that demonstrate that a state very similar to diabetes mellitus can be induced in humans with HGH (Ikkos and LUFT, 1960a). Some of our own data will be used to show this:

1. The intravenous glucose tolerance was decreased in the majority of 11 normal subjects after three days on $30 \mathrm{mg}$ of HGH daily (IKKos et al., 1962). It is noticeable that a diabetic glucose tolerance, a $\mathrm{k}$-value below 0.95 , was obtained in only three of these subjects (Fig. 9).

2. In five non-diabetic hypophysectomized patients, given $10-20 \mathrm{mg}$ HGH daily for 3-4 days, the fasting blood sugar increased (IKkos and LUFT, 1962). The peripheral uptake of glucose was measured with ${ }^{14} \mathrm{C}$ glucose and was found to be unchanged by $\mathrm{HGH}$, except for one case where it decreased (Table 1). One

Table 1. Effect of HGH on peripheral uptake of glucose in five hypophysectomized non-diabetic patients

\begin{tabular}{|c|c|c|c|c|}
\hline & \multicolumn{2}{|c|}{$\begin{array}{l}\text { Glucose in } \\
\text { plasma water } \\
\text { (mg per } 100 \mathrm{ml} \text { ) }\end{array}$} & \multicolumn{2}{|c|}{$\begin{array}{l}\text { Glucose } \\
\text { inflow/outflow } \\
\text { (mg per min) }\end{array}$} \\
\hline & before & on $\mathrm{HGH}$ & before & on $\mathrm{HGH}$ \\
\hline Case 1 & 100 & $135^{*}$ & 200 & 207 \\
\hline Case 2 & 86 & $131^{*}$ & 207 & $169 *$ \\
\hline Case 3 & 98 & $184^{*}$ & 187 & 234 \\
\hline Case 4 & 75 & $112^{*}$ & 139 & 151 \\
\hline Case 5 & 93 & $140^{*}$ & 149 & 137 \\
\hline
\end{tabular}

1 Glucose pool $(\mathrm{g}) \times$ glucose turnover rate (per cent per min) increase in peripheral glucose utilization this indicates that $\mathrm{HGH}$ in fact induced a relative decrease in glucose uptake.

3. Administration of $\mathrm{HGH}$ in a daily dose of $20 \mathrm{mg}$ for 2-3 days to two non-diabetic hypophysectomized patients induced a condition similar to the idiohypophyseal diabetes mellitus of the laboratory animal (Table 2) (IKkos and LUFT, 1960 b).

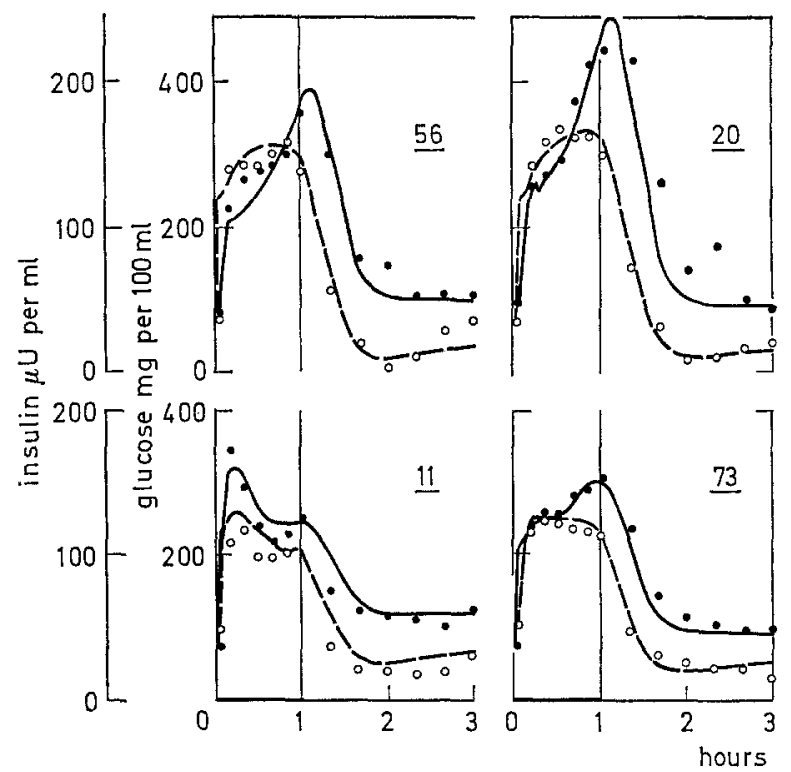

Fig. 11. Glucose infusion test in four healthy subjects. Open circles denote blood glucose, filled circles plasma insulin concentrations. The curves have been obtained by analogue computation. Whole line insulin curve, broken

line glucose curve. Glucose infusion between $0-1 \mathrm{~h}$

Table 2. Idiohypophyseal diabetes induced with HGH in two hypophysectomized non-diabetic patients

\begin{tabular}{|c|c|c|c|c|c|c|c|}
\hline $\begin{array}{l}\text { Day of } \\
\text { study }\end{array}$ & $\begin{array}{l}\text { Cortisone } \\
\text { acetate } \\
\text { mg/day }\end{array}$ & $\begin{array}{l}\text { Human } \\
\text { growth } \\
\text { hormone } \\
\text { mg/day }\end{array}$ & $\begin{array}{l}\text { Fasting } \\
\text { blood } \\
\text { glucose } \\
\text { mg } \%\end{array}$ & $\begin{array}{l}\text { Glucose } \\
\text { in } \\
\text { urine } \\
\text { g/day }\end{array}$ & $\begin{array}{l}\text { Ketone } \\
\text { bodies } \\
\text { in } \\
\text { urine }\end{array}$ & $\begin{array}{l}\text { Nitrogen } \\
\text { in } \\
\text { urine } \\
\text { g/day }\end{array}$ & $k$-value \\
\hline \multicolumn{8}{|l|}{ Case 1} \\
\hline 1 & 37.5 & & & 0 & - & 10.3 & \\
\hline 2 & 37.5 & & & 0 & - & 8.4 & \\
\hline 3 & 37.5 & 20 & 72 & 0 & & 7.9 & 1.35 \\
\hline 4 & 37.5 & 20 & & 1 & $+t$ & 3.0 & \\
\hline 5 & 37.5 & 20 & 98 & 5 & $+1+$ & 4.0 & 0.59 \\
\hline 6 & 37.5 & & 109 & 11 & + & 4.8 & 0.73 \\
\hline \multicolumn{8}{|l|}{ Case 2} \\
\hline 1 & 50 & & & 0 & 一 & 14.4 & \\
\hline 2 & 50 & & & 0 & - & 13.1 & \\
\hline 3 & 50 & 20 & 82 & 0 & - & 13.9 & 0.71 \\
\hline 4 & 50 & 20 & 134 & 21 & + & 6.8 & \\
\hline 5 & 200 & & 153 & 86 & $t+$ & 6.9 & 0.31 \\
\hline 6 & 100 & & 91 & 16 & + & & \\
\hline
\end{tabular}

must bear in mind, however, that the peripheral uptake of glucose is directly correlated with the blood sugar level. When, as in the present experiment, the blood sugar rise was not accompanied by a similar
4. Furthermore, some of our older findings elearly showed that HGH induced a deterioration of the disease when given to diabetic patients. This was most obvious in hypophysectomized, juvenile diabetics 
where already $1-2 \mathrm{mg}$ of HGH was accompanied by a dramatic response (Fig. 10) (LUFT et al,, 1958).

5. Finally, in this connection it should be mentioned that diabetes is ten times more common in acromegaly than in the general population (DAUGHADAX, 1962).

These and similar data in the literature have urged us and many others to answer the question about the diabetogenic action of HGH in the affirmative. However, our recent work on prediabetes makes it necessary to reëvaluate the concept of the diabetogenicity of HGH, and to consider it in a new context. We should like first to give a brief summary of our findings in prediabetes on which this new view is based.

1. The plasma insulin response to a standardized one-hour glucose infusion in the majority of healthy subjects showed the pattern seen in Fig. 11: an immediate and substantial rise in plasma insulin, and hyper. insulinaemia lasting for the rest of the infusion period (CERASI and LufT, 1967a).

2. In diabetic patients the insulin response was either totally absent, or, if present, delayed and sluggish (CERASI and LUFT, 1967a). This type of response was found both in patients with overt diabetes of varying severity, and in subjects with only an abnormal glucose tolerance test (Fig. 12).

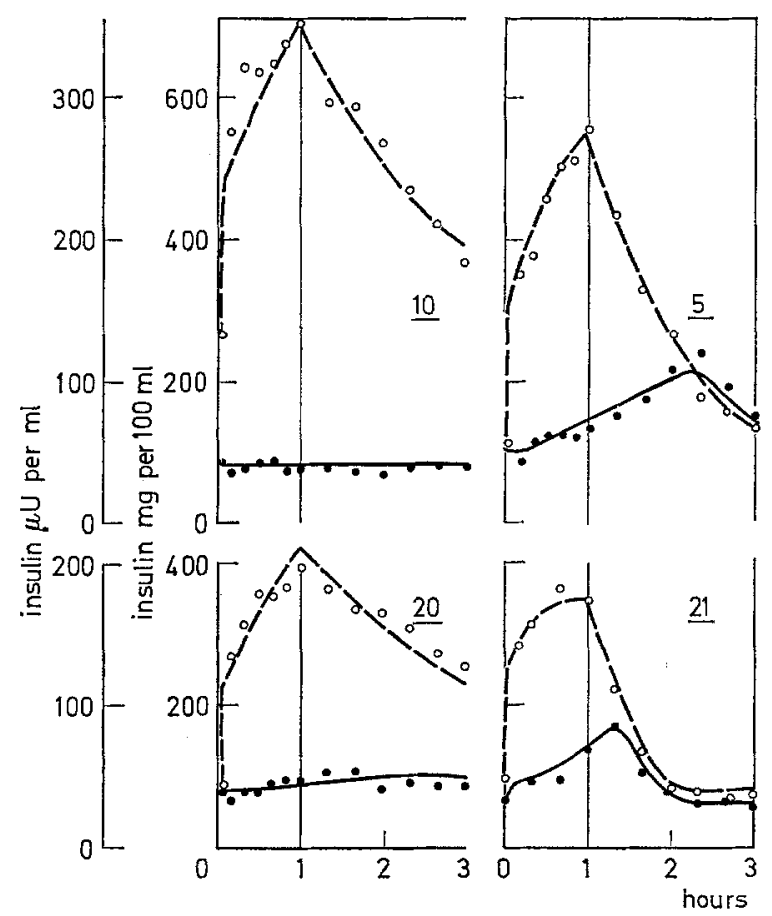

Fig. 12. Glucose infusion test in patients with manifest diabetes (top) and decreased glucose tolerance only (bottom). For symbols, see Fig. 11

3. In genetically prediabetic subjects, i.e. the healthy identical twin sibs of diabetic patients, the plasma insulin response to glucose infusion was of the same type as in diabetic patients (CERAST and IUFT,
$1967 \mathrm{~b})$. Therefore, it was concluded that a decreased and delayed insulin response to glucose is characteristic of the prediabetic state as well as of diabetes (Fig. 13).
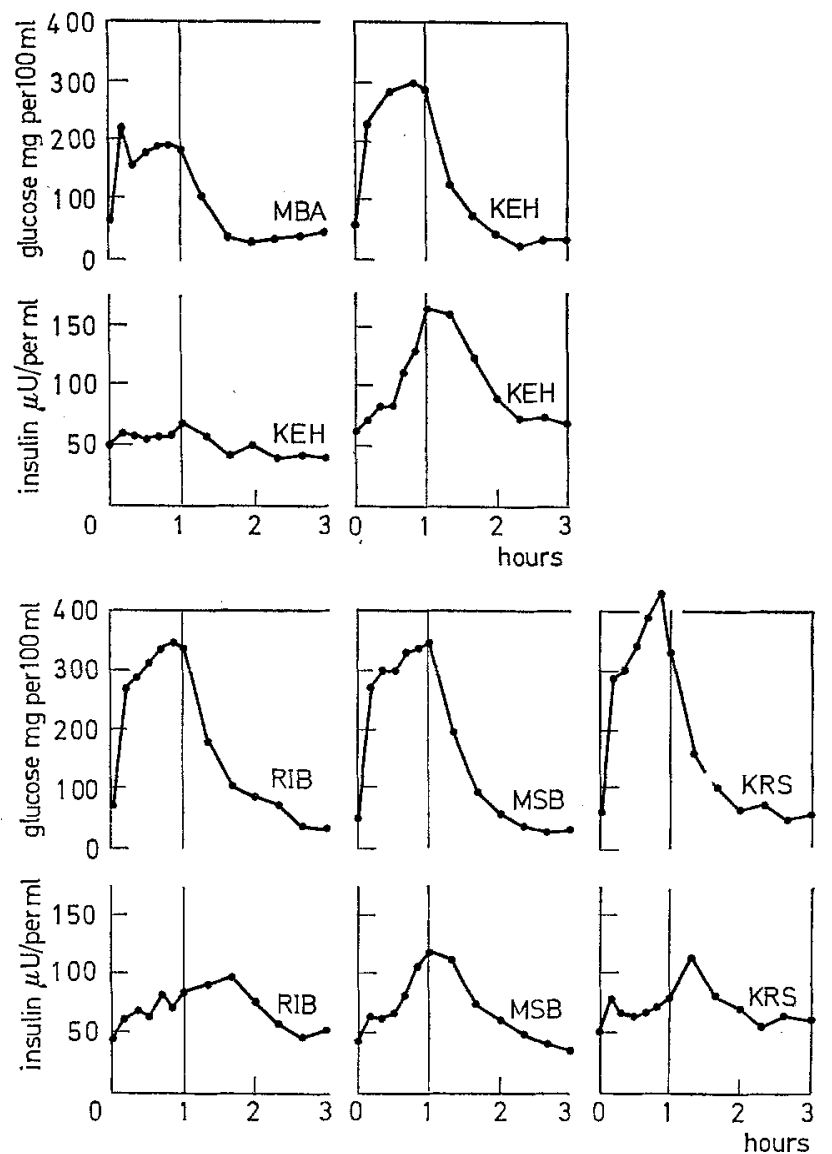

Fig. 13. Plasma insulin response to glucose infusion in healthy monozygotic twin sibs to diabetic patients. Glucose infusion between $0-1 \mathrm{~h}$

4. In 15-20 per cent of healthy, non-obese subjects with a normal glucose tolerance test, insulin response was repeatedly found to be of the diabetic type (Fig. 14). Based on the type of insulin response, these healthy subjects were presumed to be prediabetics (CERAsI and LOF', 1967a).

5. In patients with acromegaly, the insulin response to glucose infusion was found to be of one of two types, depending on whether the patients had a normal or decreased glucose tolerance (LUFT et al., 1968). In acromegalic subjects with normal glucose tolerance, plasma insulin showed an immediate and, when compared with the normal, grossly exaggerated rise in response to glucose administration. The degree of hyperinsulinism in these patients was correlated with the degree of activity of the acromegaly, the insulin response being highest in the group of patients with very active acromegaly (Figs. 15 and 16). Successful treatment of the acromegaly was always accompanied by normalization of the insulin response in these patients (Fig. 17). 
In acromegalic patients with decreased glucose tolerance the plasma insulin response to glucose infusion, regardless of the degree of activity of acromegaly, was of the type seen in non-acromegalic diabetic patients (Fig. 18). After successful treatment of the disease the low and delayed insulin response remained unaltered even in those instances where the glucose tolerance was normalized (Fig. 19).

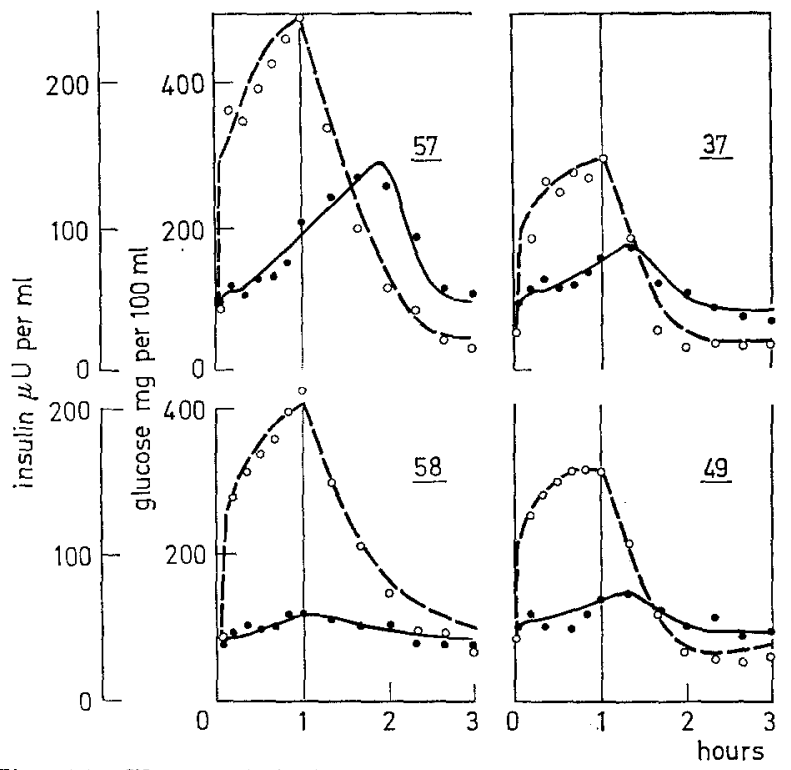

Fig. 14. Glucose infusion test in four healthy subjects with low insulin response. Note similarity of insulin response with those in Figs. 12 and 13. For symbols, see Fig. 11

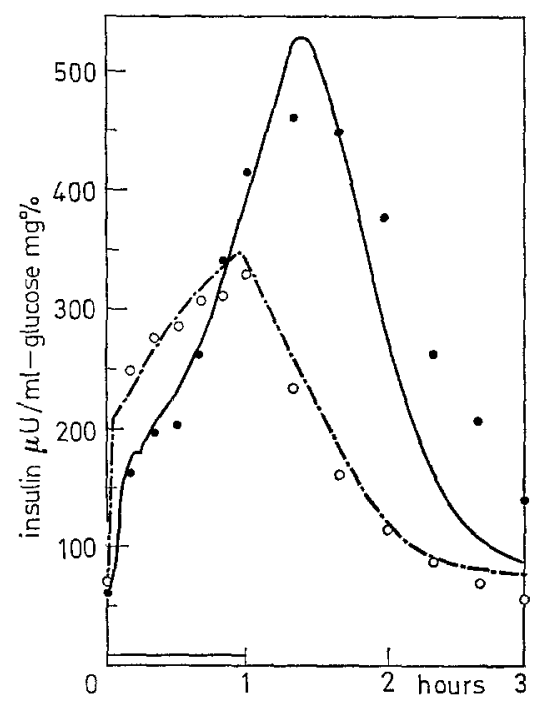

Fig. 15. Plasma insulin response to glucose infusion in patients with highly active acromegaly and with normal glucose tolerance. For symbols, see Fig. 11

Analysis of these results obtained in acromegalic patients with normal glucose tolerance gives an insight into the complex effect of HGH. Insulin release was enhanced much more than could be explained by the induced hyperglycaemia. This is in accordance with the work showing that $\mathrm{HGH}$ has a direct insulinogenic effect (Pfethfer, 1965; Bouman and Bosboom, 1965; Martin and Gagliardino, 1967). On the other hand,

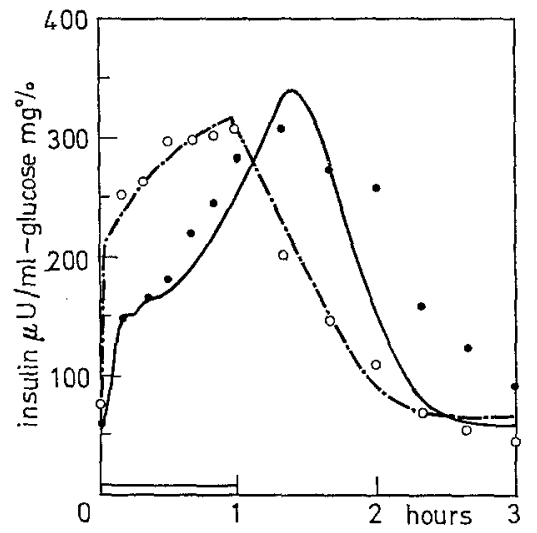

Fig. 16. Plasma insulin response to glucose infusion in patients with acromegaly of moderate or low activity and with normal glucose tolerance. For symbols, see Fig. 11

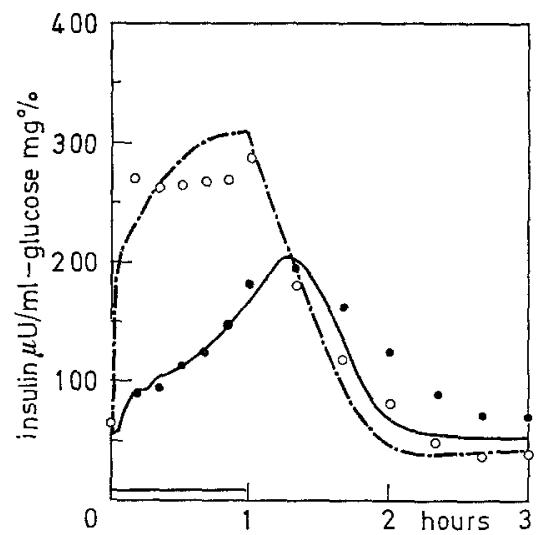

Fig. 17. Normalization of insulin response to glucose infusion after successful treatment of patients with active acromegaly and normal glucose tolerance. For symbols, see Fig. 11

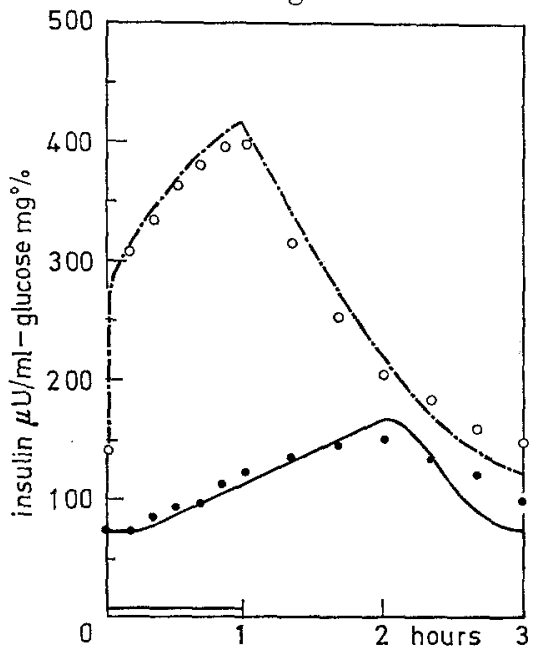

Fig. 18. Plasma insulin response to glucose infusion in patients with active acromegaly and decreased glucose tolerance. For symbols, see Fig. 11 
HGH decreased the peripheral uptake of glucose otherwise the hyperinsulinism would have been followed by hypoglycaemia.

The net result of this dual effect was a normal glucose tolerance. When diabetes appears in acromegaly this must then be attributed either to an exceptionally active state of the disease where the peripheral or diabetogenic action of HGH overcomes the secretory capacity of the $\beta$-cells; or to an inability of the $\beta$-cells to respond to the insulinogenic effect of

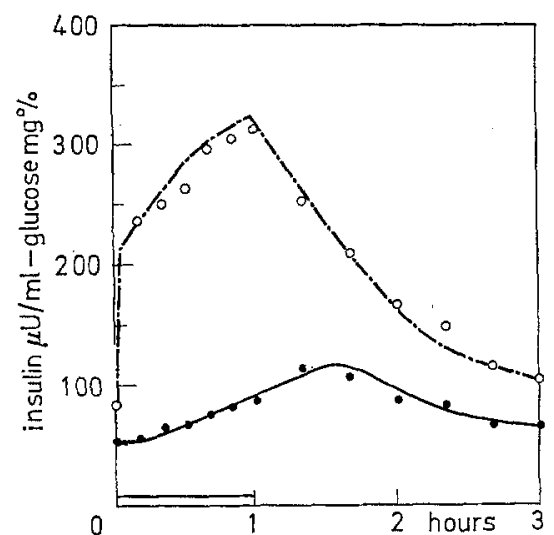

Fig. 19. Diabetic type of insulin response to glucose infusion remaining after successful treatment of patients with active acromegaly and decreased glucose tolerance, despite normalization of the glucose tolerance. For symbols, see Fig. 11
These new studies seem to give a more diversified picture of the diabetogenic action of HGH (Fig. 21). The hormone probably invariably decreases the peripheral utilization of glucose. In the presence of a pancreas capable of responding to the insulinogenic effect of the hormone, HGH - within a reasonable dose range - is not diabetogenic. In prediabetic
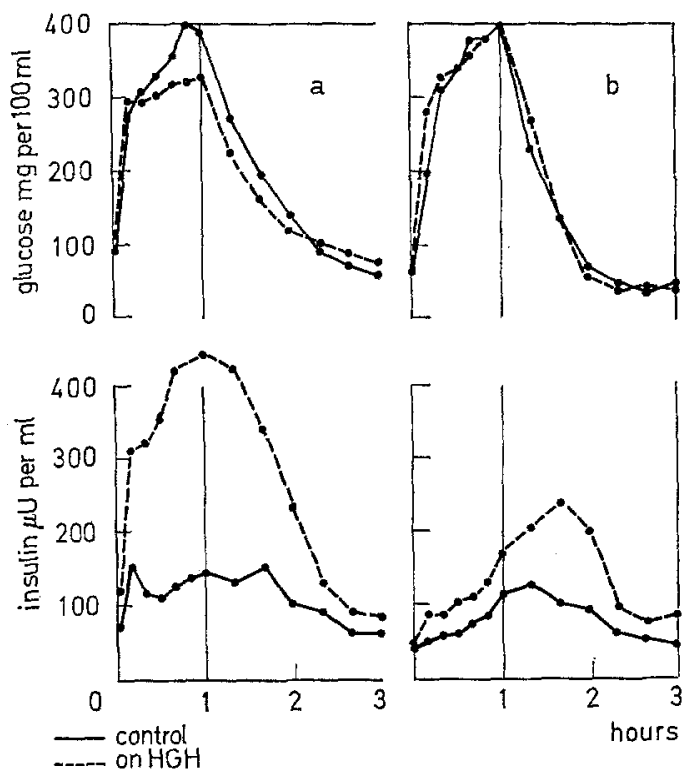

Fig. 20. Effect of administration of HGH on plasma insulin response to glucose infusion: (a) in healthy subjects with normal insulin response, and (b) in prediabetic subjects
HGH. The first alternative is unlikely since acromegalic patients with diabetes do not have acromegaly of higher degree of activity or longer duration than those with a normal glucose tolerance. Our findings in acromegalic patients support the second suggestion, i.e. an incapacity of the $\beta$-cells to produce insulin in an adequate manner.

Another finding indirectly supports this suggestion. HGH was administered to normal subjects with a normal glucose tolerance, of which some had a normal and others an impaired insulin response to glucose infusion (Fig. 20) (CERASI and LUFT, $1967 \mathrm{c}$ ). It is seen that $\mathrm{HGH}$ markedly enhanced the insulin response in the former group, whereas the prediabetic responded to a much lesser degree. This finding elucidates the sequence of events when a prediabetic subject becomes acromegalic: the $\beta$-cells are here unable to respond to the insulinogenic action of HGH, although the peripheral or diabetogenic effect of the hormone remains unaltered. The net result in such an instance will be diabetes.
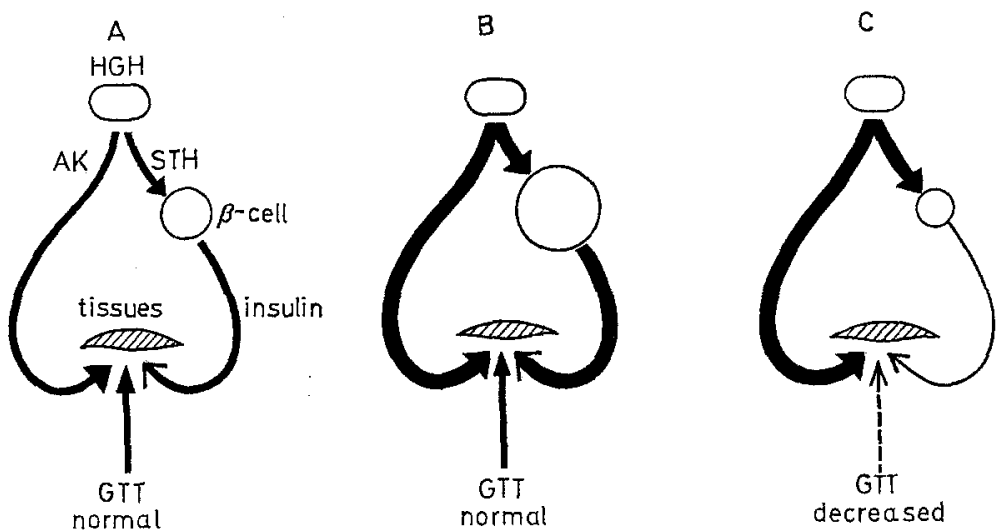

Fig. 21. Schematic illustration of development of diabetes in acrome-

A - In a normal subject

B - In a patient with acromegaly and normal glucose tolerance

C - In a patient with acromegaly and decreased glucose tolerance $\mathrm{AK}=$ adipokinetic activity

STH = somatotrophic and insulinogenic activity. Filled arrow denotes inhibition, open arrow denotes stimulation.

$\mathrm{GTT}=$ glucose tolerance test

subjects, where compensatory hyperinsulinism cannot occur, HGH appears as a diabetogenic substance. 
We have demonstrated that about 20 per cent of a group of healthy subjects were prediabetics (CERASI and LUFT, 1967a). This finding at once clarifies some results with HGH obtained earlier, which were then difficult to explain. For instance, that a diabetic glucose tolerance was obtained only in three out of 11 healthy subjects receiving high doses of $\mathrm{HGH}$ (see above). Furthermore, it becomes understandable why only about $25 \%$ of acromegalic patients develop diabetes.

From this discussion it appears that HGH as such cannot be considered as clearly a primary diabetogenic factor. At present, HGH in large doses may be regarded as an additional factor for the development of diabetes, the major prerequisite being a preëxisting prediabetic state.

It should be emphasized that we have here only been discussing a diabetic state connected with an overproduction of $\mathrm{HGH}$ or with the administration of rather large doses of the hormone. It remains to be shown whether the normal secretion of HGH with its daily fluctuations may be of any significance for the precipitation of diabetes in prediabetic individuals.

Acknowledgements. The authors wish to express their gratitude to Mr. A. Roovete, Mrs. S. Hansson, Miss C. Modíne, Miss G. SandGren and Mr. B. ANdERsson for skilful technical assistance. The computations were performed at the Division for Guidance and Control Theory, Research Institute of National Defence, Stockholm (Head: Dr. J. AgERBERG). This work was supported by grants from the Swedish Medical Research Council (Projects nos. 19X-34-02A and B67-19X-34-03B), the Swedish Diabetes Association and the Nordic Insulin Foundation.

\section{References}

Boumax, P.R., and R.S. Bosboom: Effects of growth hormone and of hypophysectomy on the release of insulin from rat pancreas in vitro. Acta endocr. (Kbh.) 50, 202-212 (1965).

CERASI, F., and R. LUFT: The plasma insulin response to glucose infusion in healthy subjects and in diabetes mellitus. Acta endocr. (Kbh.) 55, 278 - 304 (1967a).

- - Insulin response to glucose infusion in diabetic and non-diabetic monozygotic twin pairs. Genetic control of insulin response? Acta endocr. (Kbh.) 55, 330-345 (1967b).

- - The "What is inherited - what is added" hypothesis for the pathogenesis of diabetes mellitus. Diabetes, 16, 615-627 (1967 c).

Cotes, P.M., E. REID, and F.G. Young: Diabetogenic action of pure anterior pituitary growth hormone. Nature (Lond.) 164, 209-211 (1949).

Daugraday, W.H.: The adenohypophysis. In: R.N. Wilduams, Ed. Textbook of Endocrinology, p. 71. Philadelphia 1962.

Houssay, B.A., and A. Biasotti: La diabetes pancreática de los perros hipofiseoprivos. Rev. Soc. argent. Biol. 6, 251 296 (1930).
-, and E. ANDERson: Diabetogenic action of purified anterior pituitary hormones. Endocrinology 45, 627$629(1949)$.

Hunter, W.M., and F.C. Greenwood: A radio-immunoelectrophoretic assay for human growth horhormone. Biochem. J. 85, 39-40 P (1962).

IKKos, D., and R. LUFT: Aspects of the metabolic action of human growth hormone. In: G. E. W. WOLSTENHOLME, and C.M. O'Connor, Eds. Ciba Foundation Colloquia on Endocrinology, vol. 13. Human Pituitary Hormones, p. 106-129. London 1960a.

- - "Idiohypophyseal" diabetes mellitus in two hypophysectomised women. Lancet $1960 \mathrm{~b}$ II, $897-899$.

- - Effects of short-term administration of large doses of human growth hormone on carbohydrate metabolism in adult, non-diabetic, hypophysectomized women; studies with ${ }^{14} \mathrm{C}$-labelled glucose. Acta endocr. (Kbh.) 39, 567-583 (1962).

- - C.A. GEmzelt, and S. AlmQvist: Effect of human growth hormone on glucose tolerance and some intermediary metabolites in man. Acta endocr. (Kbh.) 39, $547-566$ (1962).

Levine, R., and R. LuFT: The relation between the growth and diabetogenic effects of the so-called growth hormone of the anterior pituitary. Diabetes 13, 651655 (1964).

LI, C.H., and H. Papkoff: Preparation and properties of growth hormone from human and monkey pituitary glands. Science 124, 1293-1294 (1956).

LUFT, R.: Human growth hormone and the control of blood glucose concentration. Israel J. med. Sci. 1, $1277-1283$ (1965).

- D. Ikkos, C.A. Gemzeri, and H. Olivecrona: The effect of human growth hormone in man. Lancet 1958 I, $720-721$.

- E. Cerasi, L.L. Madison, U.S. von Euler, L. Della CASA, and A. RooveTe: Effect of a small decrease in blood-glucose on plasma-growth-hormone and urinary excretion of catecholamines in man. Lancet $1966 \mathrm{I}$, $254-256$.

- - , and C.A. Hamberger: Studies on the pathogenesis of diabetes in acromegaly. Acta endocr. (Kbh.), in press (1968).

MaRTIN, J.M., and J.J. Gagliardivo: Effect of growth hormone on the isolated pancreatic islets of rat in vitro. Nature (Lond.) 213, 630-631 (1967).

Preiffer, E.F.: Wachstumshormon und Insulinsekretion: Die Verhältnisse unter normalen und pathologischen Bedingungen. In: KteIN, Ed., Wachstumshormon und Wachstumsstörungen. Das Cushing-Syndrom, p. 41-55. Berlin 1965.

RABEN, M.S.: Growth hormone: anabolic and anticatabolic agent. Diabetes 14, 374 (1965).

Rabinowitz, D., T.J. Merimee, J.A. Burgess, and M. B. BaltimoRE: Growth hormone-insulin-interaction. Fact and speculation. Diabetes 15, 905-910 (1966).

RotH, J., S.M. GLICK, R.S. Yalow, and S.A. BERSon: Hypoglycemia: A potent stimulus to secretion of growth hormone. Science 140, 987-988 (1963).

YouNG, F. G.: Permanent experimental diabetes produced by pituitary (anterior lobe) injections. Lancet 1937 II, 372-374.

Prof. Dr. R. LuFT

Department of Endocrinology and Metabolism, Karolinska Hospital

Stockholm 60, Sweden 